\title{
The Revival of Islamic Architecture using Parametric Algorithms
}

\author{
Presented by Arch/ Sara Mahmoud Ahmed Fouad, Architecture Department \\ Prof. Dr.: Mohammed Alaa Mandour, Architecture department, Faculty of Engineering - Mattaria \\ Assoc. Prof. Dr.: Sahar Morsy Mohammed, Architecture department, Faculty of Engineering - \\ Mattariah
}

\begin{abstract}
Islamic architecture was ignored because of the appearance of the technology especially parametric design. This led to the transformation of the architectural form from static blocks to dynamic blocks in addition to borrowings from ecological natural forms that focused on producing idea. So Islamic architecture faced the challenges of advanced technology in linking heritage with contemporary. This is to ensure continuity and communication with the movement of life and the expansion of the circle of civilized contacts between peoples. Then it's necessary to find a methodology to link between parametric architecture and Islamic architecture for its revivalism.
\end{abstract}

Keywords: Islamic architecture, parametric architecture, modern Islamic architecture, revival.

\section{1- Introduction}

If Islamic architectural elements emerges in different eras and in any countries. It effects on them despite of the changes in their construction methods and materials. Finally it obtains a new Islamic building that revivals the authenticity values and the social values of Islamic society. So Islamic architectural theory is the universal theory of all time and place, rather than the local theory emanates in a particular place and time. It is the theory that works to deal with variables for every time and place ${ }^{(1)}$.

So this research undergoes an analytical and applied study to check the possibilities of reviving the Islamic Architecture. This research aims to find a methodology to link between parametric architecture and Islamic architecture for its revivalism that applies parametric thinking to achieve this aim:

The analytical study will be applied on new buildings with Islamic details, patterns....etc. in the last ten decades by identification the design principles, materials, construction system, environmental treatments, patterns, parametric Islamic elements and metamorphosis from parametric design to Islamic parametric design. Then it will be compared with Islamic architecture to show the similarities and differences between them.

This study will be evaluated through some elements which are:

- Design principles: to explain the designing idea of the building which includes:

1-The mass building: if it is (Traditional: like the old Islamic building or unique: as it is not similar to any other Islamic building).

2-Symmetry: to explain if the right façade of the building is similar to the left side or not which represents in the evaluation as (Symmetry if they are the same, un Symmetry if they are different). 
3-Stability: which means if the sides of the building are straight lines forming right angles or not which represents in the evaluation as (Stable if they form right angle, un Stable if the sides are inclined).

4- Repetition: if the mass buildings and elements repeat before or not (repeat if it is like the old one as it, Unrepeated if they are different or same elements but in different shape).

- Material: the material used in building, if they are (Traditional: it used before in other buildings or they are modern).

- Environmental treatment: the methods used to save energy (Traditional: which used in the old Islamic buildings or modern, which did not used before in the Islamic buildings).

- Construction system: the structure system of the buildings if it is (Traditional like the old Islamic buildings or modern, which did not used before in the Islamic buildings).

- Parametric Islamic elements or Patterns: which used to decorate the building if they are (Extracted from past or modern).

- Metamorphosis: in which explains the changed that happened to the building when parametric design uses to design the building.

- Economic cost: it means if building the Islamic parametric buildings are (expensive or Unexpansive).

\section{2- Literature Review}

Islamic architecture includes several types such as: mosques, which is the finest architecture for Muslims, palaces, houses, and schools. Muslims excels in architecture in all its forms. It benefits from previous civilizations then they develops them in accordance with their faith and religion, to be an Islamic model of their own. It took the appropriate model for it as it is developed in a manner that didn't contradict the Islamic faith and continued so far suitable for man and place and time. They have an architectural thought that is not associated with a specific time or certain elements. But it associated with fixed principles and relied on elements that accept evolution with time. The main principle of Islamic architecture means the shape is symmetry around its axes, regularity, and repetition, straight lines, right angles, corners, and simple repetition of elements and patterns ${ }^{(2)}$.

Recently, a paper is studying "The development of the principles of the Elements of Islamic architectural by using parametric algorithms" which talks about the Islamic principles that affected by the parametric principles in which some principles changed, some disappeared and some upgraded (3).

The published paper talks about Islamic geometric pattern; about a method for the analysis of metamorphosis in traditional Islamic geometrical patterns using a parametric model is presented to extract a new from traditional. It talks about the Islamic geometric patterns which derived from Islamic art. They tends to avoid using figurative images. So it makes frequent use of geometric patterns which have developed over the centuries. They often built on combinations of repeated squares and circles, which may be overlaps and interlaces, to form intricate and complex patterns, including a wide variety of tessellations. The complexity and variety of patterns used evolved from simple stars and lozenges in the ninth century, through a variety of 6- to 13-point patterns by the 13th century, and finally to include also 14- and 16-point stars in the sixteenth century ${ }^{(4)}$.

Many researches have analyzing the geometry of the IGP by isolating cells and populating them to reconstruct the corresponding pattern. Recently designers use this knowledge to create modern versions of IGP designs from the scratch. The first step isolates the cell to delineate the fundamental unit. The fundamental unit is founded by decomposing the cell to its constructional non repeating components. This operation generates the fundamental unit for the pattern, which is defined as the minimum motif that cannot reach with symmetry. Once the fundamental unit attains we proceed to reconstruct its geometry with a parametric model; a geometrical construct with variable attributes (properties) that allows the exploration of design variations with ease. By defining certain rules that govern the parameters, the designer can to explore the patterns in a manual manner. Islamic geometric 
patterns have simple strict rules for creation and infinite number of possible patterns, it metamorphosis's into contemporary Islamic patterns that follows parametric architecture. Patterns can emphasize cultural characteristics, and determining identity ${ }^{(5)}$.

There are varies studies about re-skinning the facades of parametric buildings. There are some examples about Islamic parametric facades but it just concerning with the Islamic patterns that uses in the façade.

While this study links between Islamic architecture and parametric design to revival the first one by using the second through linkage between Islamic architecture with modernity. It analysis's many buildings in different countries by comparing the elements and the patterns in these examples to the elements and patterns of the traditional Islamic architecture and make a survey to obtain a methodology to link between parametric architecture and Islamic architecture to revival Islamic architecture that applies parametric thinking.

\section{3- Parametric Design}

Parametric design was based on mathematical thinking to express the ideas of a function or aesthetic, whether it related to architecture or separated from them with emphasis on the symbolic value through the intent of thought and response form and often deal with its environment in finding aesthetic solutions in the environment, climate, culture and function ${ }^{(6)}$.

It is about the use of variables and algorithms to generate a hierarchy of mathematical and geometric relations that allows to generate a certain design, but to explore the whole range of possible solutions that the variability of the initial parameters may allow. The division of parameters can be continued endlessly into smaller and more detailed attributes. The accuracy of the details depends on the limits of management and creativity of each working on the stage object ${ }^{(7)}$.

These designs are based on the structural diffusion principle, which is extended in different directions in a way that is free from constraints and expresses the idea that is consistent with nature or function. This means that no more axes, no more regularity, and no more symmetry nothing that smacks of the great architecture of the past. "Avoid repetition, avoid straight lines, avoid right angles, avoid corners, and avoid simple repetition of elements ${ }^{(8)}$.

Most of the previous studies focused on the study of Islamic motifs, extract new from tradition despite the richness of Islamic architecture with many elements such as: domes, minarets, gates, doors......etc. While in this research we will make a comprehensive revivalism on all Islamic elements. Through analytical and applied Study on examples of Islamic parametric building in different countries to find a Methodology to revival Islamic Architecture using Parametric Algorithms.

\section{4- The analytical study:}

This study will be done on International and Arabic Islamic parametric buildings in the last decade. The buildings were chosen according to: due to the existence of the elements of Islamic architecture or the Islamic patterns in them. The function of most of the buildings are Islamic centers or offer services to Muslims so their design affected by it. The existence of buildings in an Arab city or a city with an Islamic history.

\section{4/1- Islamic Cultural Center in Piedmont}

Country: Italy,

Architect: WAFAI Architecture and Fragomeli + Partners,

Opening: will be presenting in 2020.

The project features a mosque and it is a center for cultural and social activities, a space that promotes constructive dialogues. The idea of an educational facility was borrowed from the traditional configuration of mosques where during the day it "used to be spaces for educational purposes for children, where they learn writing and reading", and transforms during the night into "a forum to 
discuss cultural and social affairs, where the people of the society gather" to exchange and share cultural values. There is a public space where people meet, contains a big pray hall in the central part of the cultural center surrounded by a multi-function space, separated by an arcade, a seamless transition with the plaza of water. The roof structure rises gently to form a dune that recalls the traditional dome, becomes the only architectural element visible from the outside, it is made of hundreds of cubic modules that allows daylight to filter into the prayer hall ${ }^{(9)}$. 


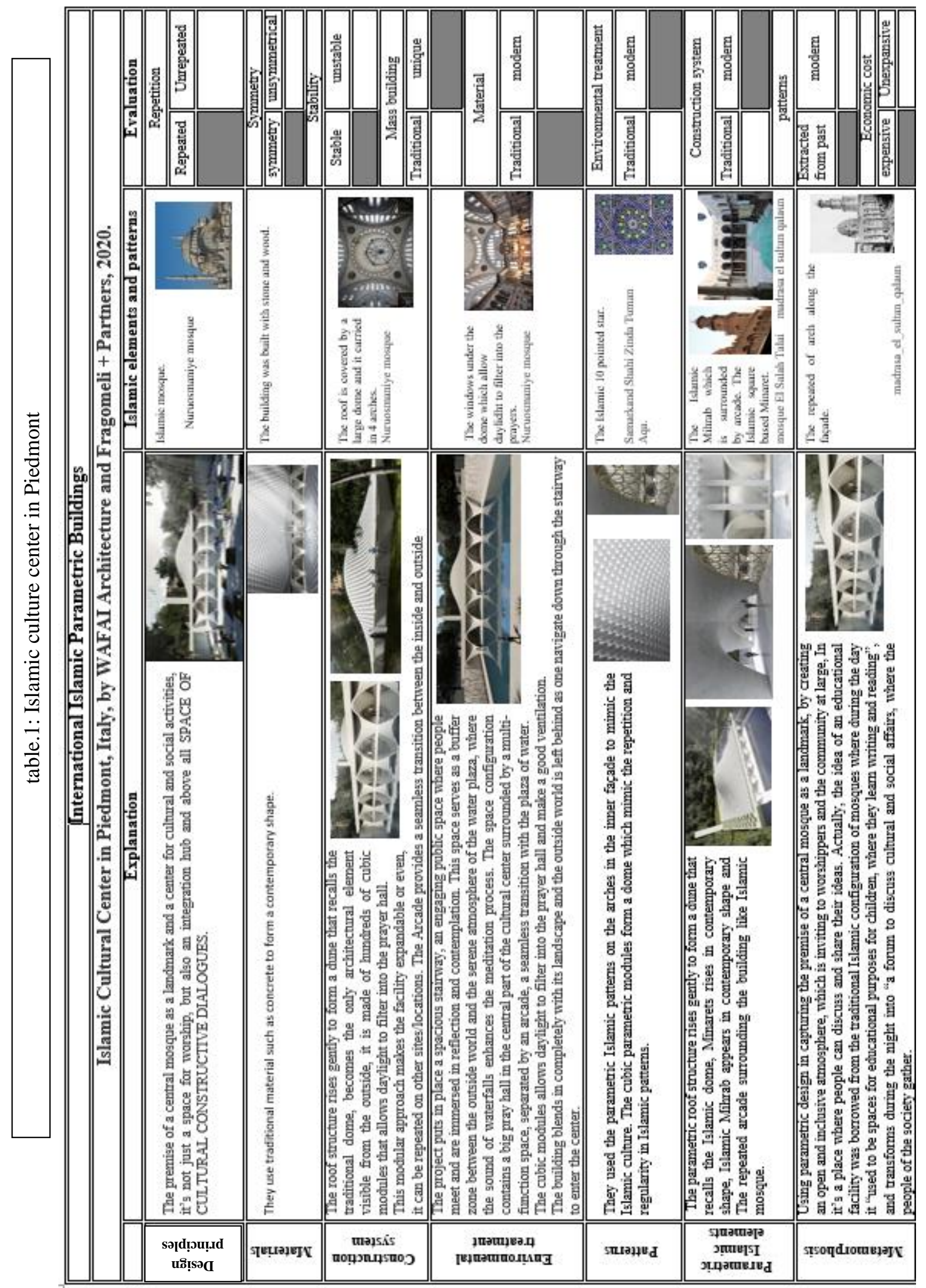




\section{4/1/1- Results from analytical study of Islamic Cultural Center in Piedmont}

- There was a similarity in the concept design with the old Islamic mosque in which there was (a large dome, the minaret and an open arcade).

- The mass building was symmetry and stable which is not compatible with the principles of the parametric design but when it used with Islamic architecture it maintained its principles.

- There was a similarity in the building materials but with a different in a construction system.

- Using the same environmental treatment (the lake outside the building, an open arcade and the dome which makes a good ventilation and a small open holes in the ceiling to penetrate light).

- Used a 10-pointed Islamic star in the exterior wall with a copper and glass.

- Using the Islamic elements but in a parametric way in applying the principle of Islamic mosque with the principles of parametric design.

- Finally the mosque of the Islamic center looks like the old Islamic mosques but in an Islamic parametric design.

\section{4/2-Da Chang Muslim Cultural Center}

Country: Hebei, China

Architect: Architectural Design \& Research Institute of Scut,

Opening: 2015.

The project is supposed by the local government to be an iconic design, introducing Dashing's particular culture and enhancing the soft power of the city. The national palace is thus endowed with multiple functions, serving not only as the recreation center of the city but the essential culture site for the introduction of local religion and history as well. Dachang country is Muslim enclave near Beijing. To revive the Islamic culture and improve the quality of culture life, it's a complex integrating the functions of theater, exhibition, convention and community center. Based on a traditional mosque with new materials and technologies.

The surrounding arches shrinks into elegant curves from the bottom up, the dome sees the translation and abstraction of Islamic symbols rather than simple mimicking. The dome constitute with petaloid shells and creativity transform the interior space into semi exterior roof garden flooded with the sunshine, fresh air and ventilation ${ }^{(10)}$. 


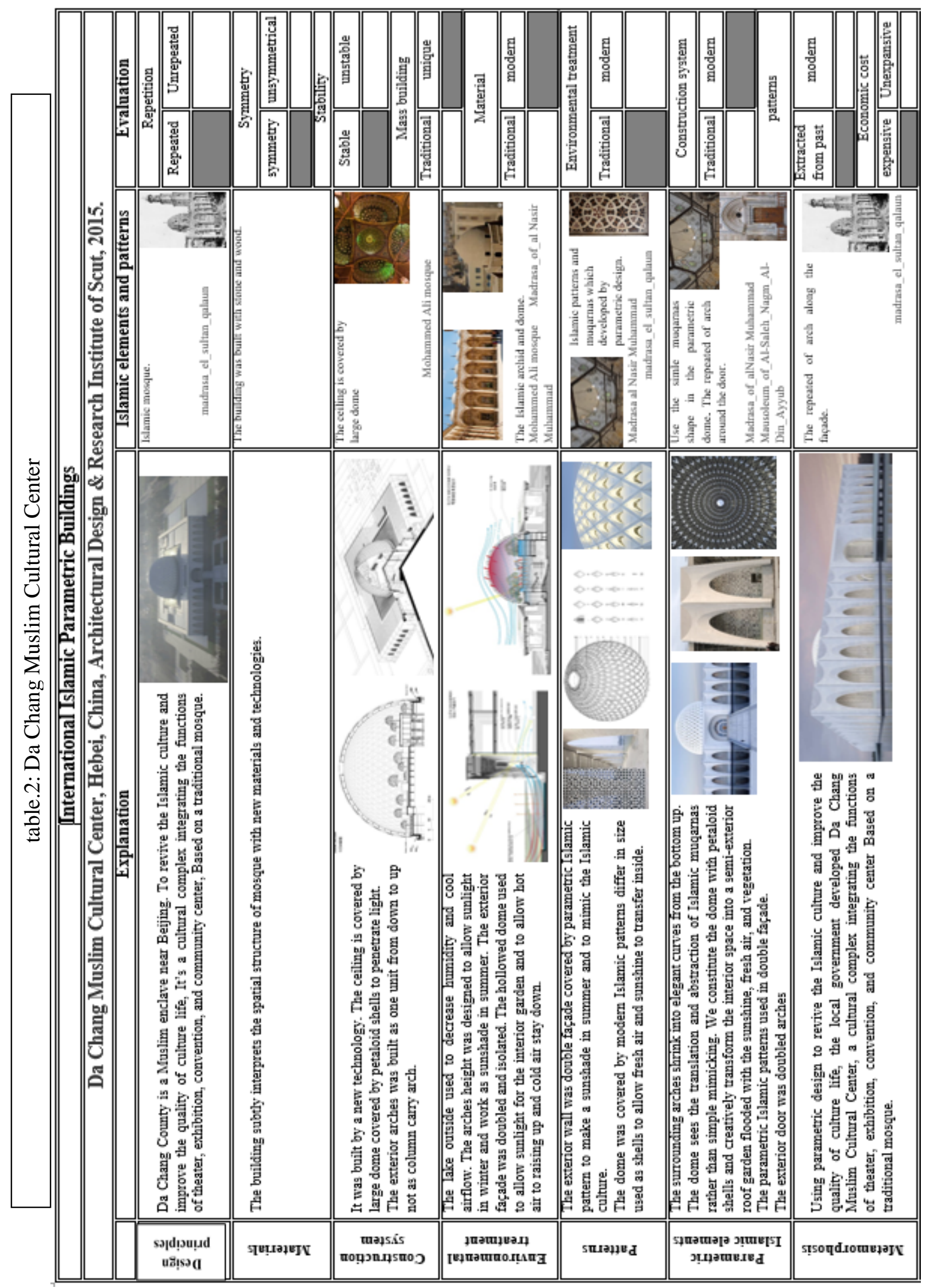




\section{4/2/1- Results from analytical study of Da Chang Muslim Cultural Center}

- The concept of the center based on a traditional Islamic mosque in using (the dome in the, open arcades, open holes all over the dome and decorating by using Islamic tessellation).

- The mass building is symmetry, stabile and repeated in arches like old mosques.

- Using modern building materials.

- It was built by a new technology to represent the beauty of the traditional Islamic architecture.

- Using the traditional Islamic environmental treatment in placing a large dome decorated by small opening holes, double wall the exterior covered with arcades and the interior covered with Islamic tessellation.

- Using the elements it looks Islamic but it designed by using parametric algorithms like the dome it contain opening like old one, repeated arcades and the arch started from the ground to the other point in one line not like the old one and the inside garden and transferring the Islamic motifs to parametric Islamic motifs.

- Finally the building appear like a traditional Islamic mosque but really it's not a mosque indeed but it looks contemporary design because of using parametric algorithms so the result is parametric Islamic building.

\section{4/3- Yinchuan Exhibition Center}

Country: Northwest China

Architect: Sure Architecture

Opening: 2012.

Ningxia for long time has a great culture influence of Muslim Style. Around the whole city you can find this culture present. Yinchuan Exhibition Center is designed to unite the Chinese and Arabic Axis while also functioning as a premier cultural institution. The building's perforated facade features carved patterns which it look like the Islamic mashrabiya that allow natural ventilation and daylight to enter the building. The mashrabiya is the important element in this design, as it took its appearance through decoration that does not depend on repetition and continuity, trying to give a modern spirit to this element, and it worked as a glass shell surrounding the building. The building is centered on a sprawling main atrium that connects the floors and allows visitors to view the entire museum from the atrium level like the Islamic Wekala and Islamic houses. Aside from being a new cultural landmark, the museum is also a model of energy-efficiency ${ }^{(11)}$. 


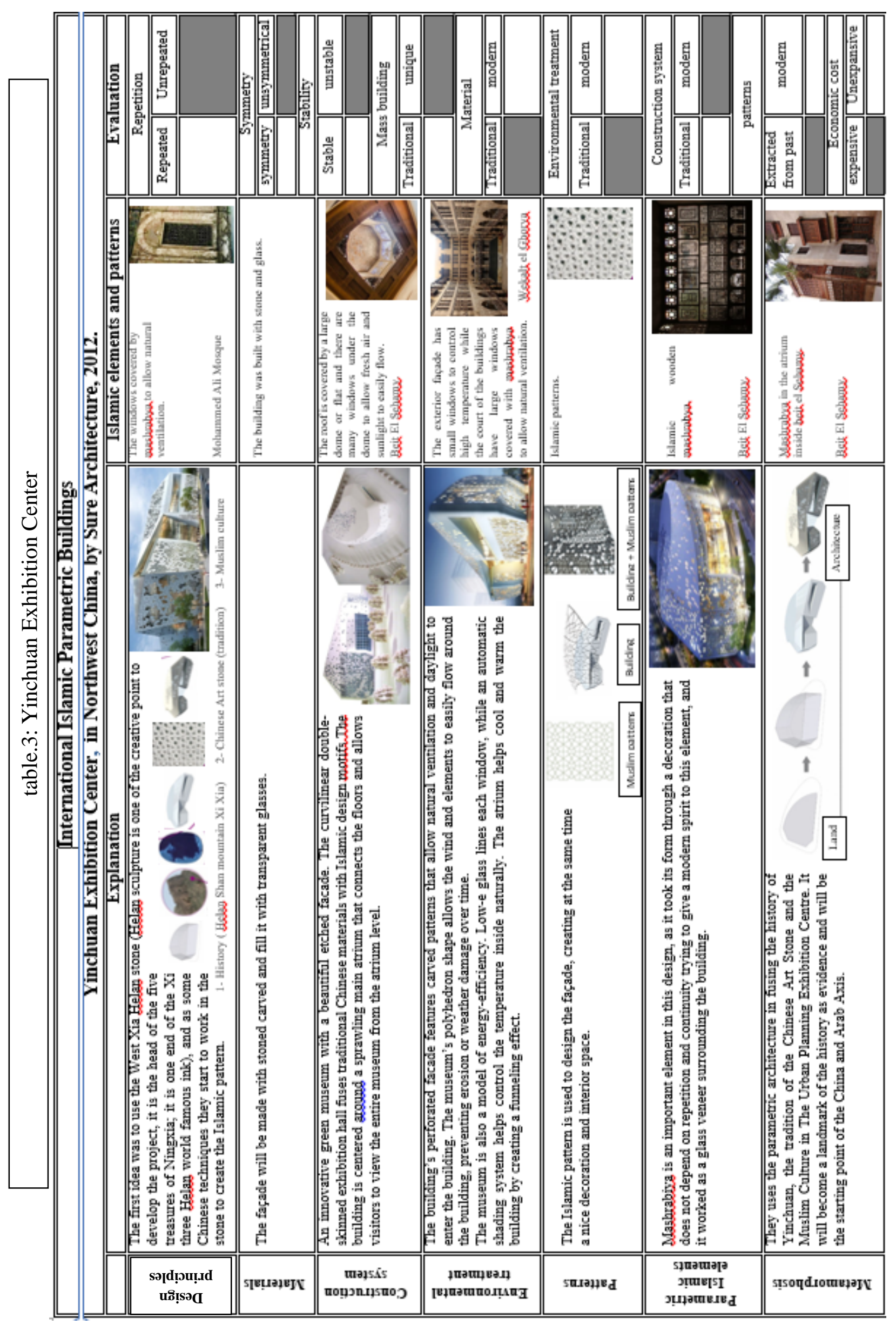




\section{4/3/1-Results from analytical study of Yinchuan Exhibition Center}

- The concept of the center is by mixing the history of China by using the shape of historical Chinese stone and the traditional Islamic design by using the concept of Islamic Mashrabyia all over the building.

- The mass building is not symmetry, unstable like stone and not repeated which are the principle of parametric design.

- Using traditional material building by a new construction system.

- Using a traditional environmental treatment (a double wall atrium like Islamic wekala, parametric Islamic motifs allows a good ventilation and penetrate sun light to allow in.

- The center depends on the Islamic motifs to represent the Islamic architecture in which it depends on the Islamic mashrabyia used with parametric algorithm to form a parametric Islamic patterns but it still applied the principles of it applying the main concept of mashrabyia which is dispersion the sunlight in the south facades and allows good ventilation not its shape.

- Finally the building is compatible with the environment in mixing the history of China and Islamic architecture with parametric algorithm to obtain a parametric Islamic building.

\section{4/4- The Abu Dhabi Louvre Museum}

Country: Jean Nouvel

Architect: Abu Dhabi

Opening: 2018

Louvre Abu Dhabi is a new cultural beacon, bringing different cultures together to shine fresh light on the shared stories of humanity. Inspired by the domed roofs and geometric motifs of ancient Islamic architecture, but realized with contemporary materials and state-of-the-art engineering, it is a civilization museum that celebrates the past while looking toward the future. Modeled after a traditional Arab medina, the museum consists of 55 individual buildings, clad in ultra-high performance concrete, loosely arranged around stone-paved plazas and deep reflecting pools. Above, an intricate metal dome provides refuge from the desert sun, unifying the detached galleries and various ancillary buildings under its shade. During the day, natural light filters down through the metal latticework of the dome like sunrays passing through palm leaves in an oasis, dappling the concrete and shimmering on the water. This effect, which Nouvel has dubbed the "rain of light," is made possible by the dome's multi-layered structure ${ }^{(12)}$. 


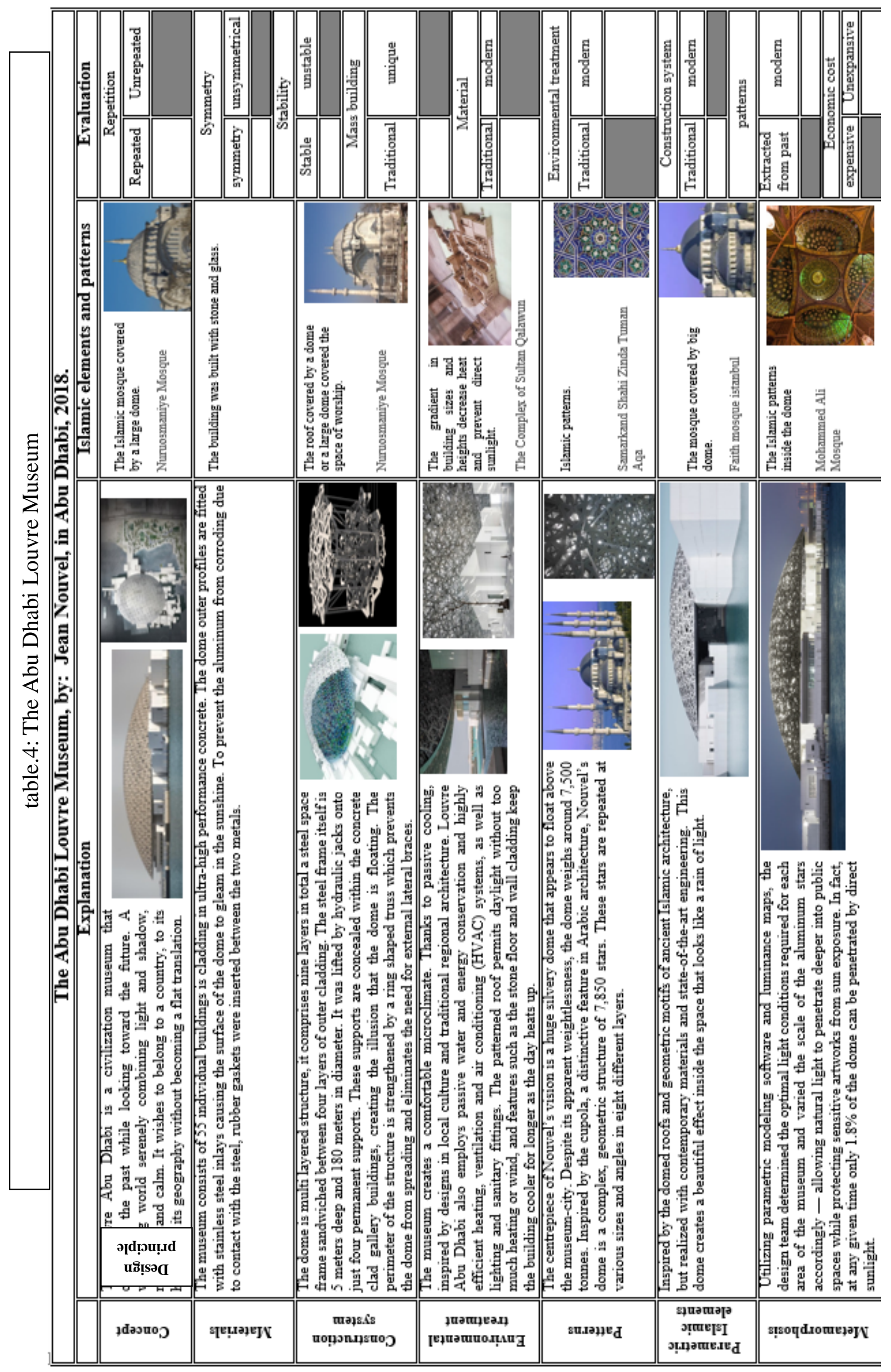




\section{4/4/1-Results from analytical study of The Abu Dhabi Louvre Museum}

- Using a large dome covered the buildings make the building similarity to the traditional Islamic mosque but it actually not a mosque.

- The mass building is unsymmetrical, repeated (in using Islamic dome) and unstabile (which the dome looks floating) so it's compatible with the principles of the parametric design and with Islamic architecture.

- Using a modern material building and a modern construction system (multi layers of steel dome) to built a traditional Islamic dome.

- Using a traditional Islamic environmental treatment in a large dome centered the building to allow good ventilation, using an Islamic motif in steel truss with parametric algorithms covered the dome in four layers and different sizes allow the sun light to penetrate the building like the small holes in the traditional Islamic dome.

- Using Islamic elements designed by using parametric algorithms like the dome it contain holes for good ventilation and it decorated by Islamic motifs but in different sizes and different material which differ from the old one.

- Finally using parametric algorithms with the Islamic elements with modern material and new construction system transfers it into parametric Islamic building.

\section{4/5-King Abdullah Petroleum Studies and Research Center,}

Country: Riyadh, Saudi Arabia

Architect: Zaha Hadid,

Opening: 2016

The project is designed with a future outlook in terms of continuous development and through its integrated language to maintain its visual coherence. The hexagonal cells that make up the project are not uniform or repetitive in shape, but rather their shape is designed according to their positioning among themselves to respond to the requirements of the environment and internal distribution through a volunteer space formation strategy to form the internal spaces of the project components and distribute them in the appropriate places for their function. The design of the project has semi-solid blocks from the outside that have inside shaded courtyards with unique geometric shapes designed to provide natural lighting inside the building and allow air to move inside the courtyards to create a natural way for ventilation and the courtyards form an environment with intermediate ventilation between the hot outside climate and the cold internal climate of the building is Conditioner like the old Islamic houses ${ }^{(13)}$. 


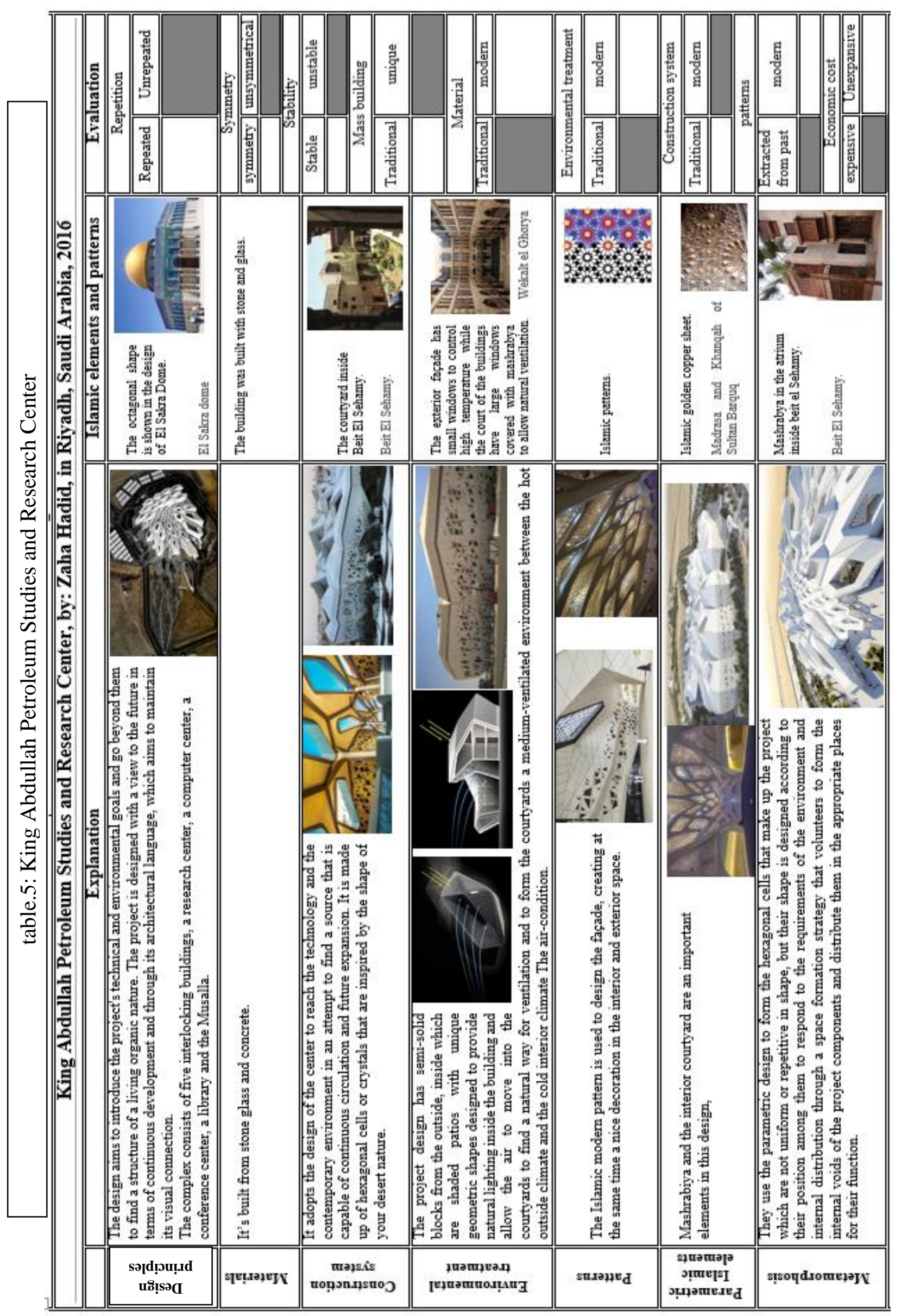




\section{4/5/1- Results from analytical study of King Abdullah Petroleum Studies and Research Center}

- The concept of the center based on the Islamic hexagonal shape which is repeated in different sizes and placed surrounded a shaded atrium in the middle like an Islamic wekala.

- The mass building is unstable, unrepeated and unsymmetrical which it's the principles of parametric design.

- Using traditional material building but uses to form a modern construction system.

- Using traditional Islamic treatment in making an atrium and the building surrounded it using the concept of Islamic mashrabyia to allow good ventilation.

- The center depends on the Islamic motifs to represent the Islamic architecture in which it depends on the Islamic mashrabyia used with parametric algorithm to form a parametric Islamic patterns, the mihrab in the mosque inside the center it decorated the mihrab by using Islamic motifs centered the wall of qibla but it designed with a parametric algorithms.

- Finally using parametric algorithm with Islamic principles forms a parametric Islamic building.

\section{4/6-The Qatar Faculty of Islamic Studies}

Country: Doha, Qatar

Architect: Mangera Yvars Architects

Opening: 2014

The Qatar Faculty of Islamic Studies and Education City Mosque takes much of its inspiration from the traditional architecture of the Arab and Muslim world. The revival of the traditional Islamic madrasa model, in which seeking knowledge and worship are combined in one complex. Their concept studies with the metaphor of knowledge leading to enlightenment re-ected in two ribbons: a ribbon of knowledge and a ribbon of light. The two intertwine, creating a dynamic form with a lower sweeping mass of classrooms and a higher volume for the mosque, ending with the 'ribbons' then ascending towards the sky marking the minarets of Education City mosque.

We are going to analyze them due to the evaluations elements that explained before and comparing them to the traditional Islamic architecture that they inspired from to know the difference and the similarity in the Islamic elements to obtain a methodology to develop contemporary Islamic architecture with parametric algorithms ${ }^{(14)}$. 


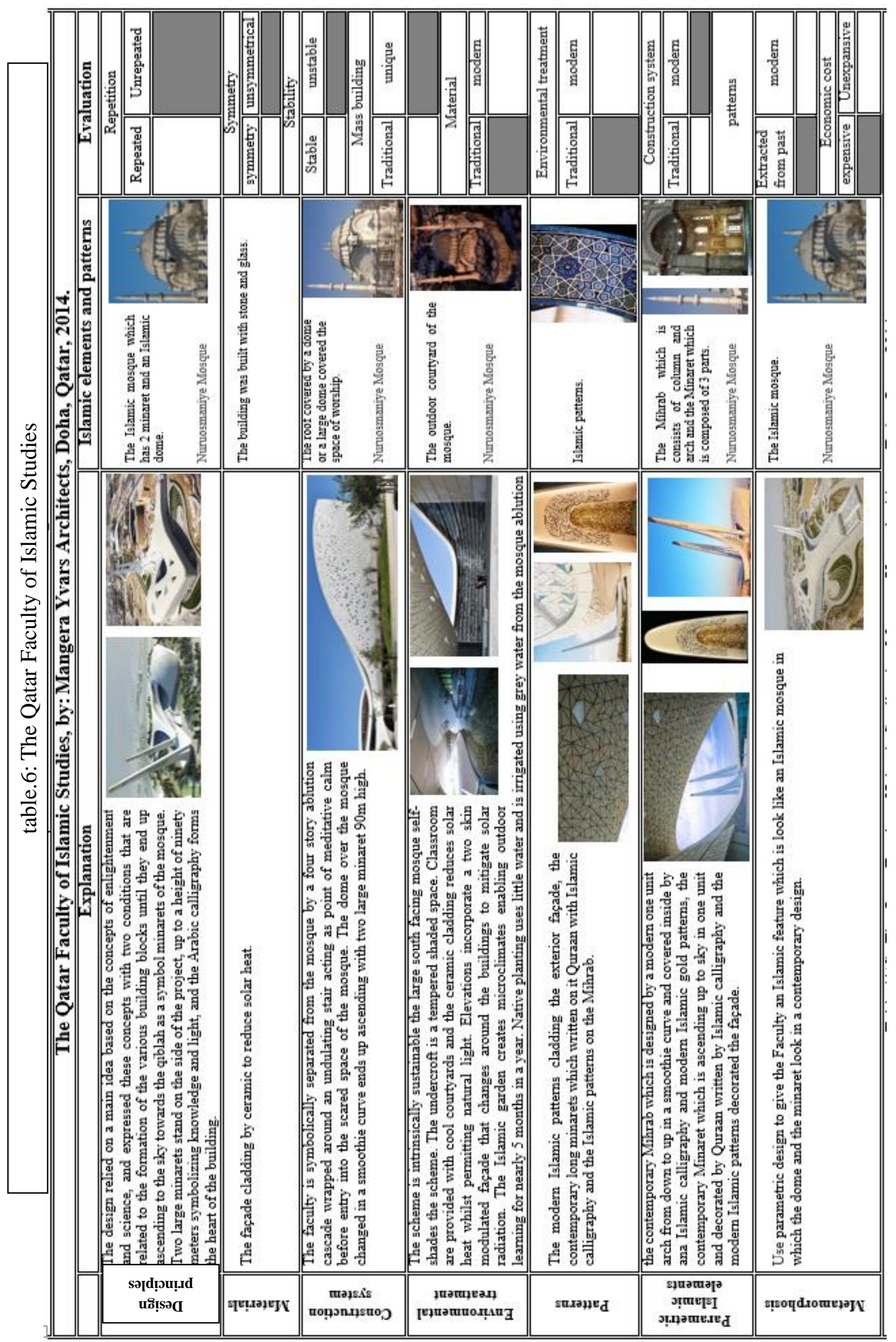




\section{4/6/1- Results from analytical study of The Qatar Faculty of Islamic Studies}

- It's an Islamic center so the concept based on an Islamic mosque (a dome centered the center, the mass building ended by two high minarete and a parametric motifs all over the building).

- The mass building is unrepeated, unstable and unsymmetrical which difference from the principles of traditional Islamic mosque.

- Using a modern material building with modern construction system to built a faculty represent a concept of Islamic mosque by using a parametric algorithm.

- Using traditional Islamic environmental building like (an open atrium centered the faculty, selfshaded facades by using parametric Islamic motifs all over the building and an open garden surrounding the faculty like the old Islamic courtyard.

- Using parametric patterns all over the facades and in the mihrab inside the mosque in the faculty, using the Arabic calligraphy along the inside facades.

- The center depends on the Islamic motifs like Islamic mashrabyia used with parametric algorithm to form a parametric Islamic patterns, the minarets, the dome and the mihrab.

- Finally the faculty appeared like traditional Islamic mosque but in a parametric design.

\section{5- The results from the analytical study}

- The general concept of the character of Islamic architecture includes the Presence of elements such as domes, minerates, mihrab and round arches, tunnel vaults, and richly decorated arabesque and calligraphy, so parametric design respect their presence but changed their form into a parametric form.

- The principles of parametric design affected by principles of Islamic architecture in which it become repeated, symmetry and stable in some building which it looks like the old one from the first sight in its mass building while the elements look parametric in its design.

- An important characteristic of Islamic architecture is its sustainability and its environmental treatment to provide good lightening, ventilation and cooling so parametric design respect this character and developed it and re-represented it in Islamic parametric design.

- Islamic architecture is also renowned for its rich ornamentation, which has been admired and appreciated by many Western scholar so parametric algorithms redesigned in a contemporary design which fits the modern design of the building.

- The building material may be traditional or modern because parametric design deals with it in a contemporary parametric construction system.

- The Islamic parametric building must extracting from the past Islamic architecture.

- When parametric algorithms used with Islamic architecture changed in shape not in the principles of its element.

- Finally Islamic architecture can be contemporary, progressive and inclusive but, above all, can act as a beacon of hope in opposition to nihilistic conflict that has gripped the Middle East region. 


\section{5- The applied study}

The survey examines the results of the previous analytical study by studying a number of buildings (inside Egypt and Arab and foreign countries) that represent Islamic architecture but it designs by using the parametric algorithms, and presents them to architects and non-architects to identify the views of both teams who evaluate these buildings through some architectural elements in order to reach $\mathrm{A}$ methodology to revival modern Islamic architecture.

\section{(5/1) The aims of the applied study}

It aims to survey the impressions on a group of Islamic parametric buildings from different countries to identify:

- Did parametric design succeed to revival modern Islamic architecture? (Will the audience accept it or not?)

- Did the design of the elements of the Islamic architecture changed or not?

- A methodology to revival the modern Islamic architecture by using parametric algorithms depends on the evaluation elements in the survey.

\section{(5/2) Designing the survey form}

The survey form includes two main parts: $\mathbf{1}^{\text {st }}$ which includes personal data about the individual to whom the buildings will be presented, and that data includes architect or not architect. 2nd in which the individual places a sign $(\sqrt{ })$ next to the evaluation he seems appropriate to the question and what he sees and senses. It takes into account to place detailed pictures of each building in order to clarify the building's vision in front of it and to fully recognize it and allow him to answer the questions clearly.

\section{(5/3) Criteria for selecting the study sample}

The choice of the four buildings depended on being in different countries to display four different ideas of Islamic culture to demonstrate the extent of the success of parametric architecture in the development of Islamic architecture in each country and whether these ideas fit the general taste or not and know the basics that must be available in the building to revival modern Islamic architecture. Emphasis is placed on some key characteristics:

- Some of these buildings should be newly constructed or to be implemented in order to knew the latest developments in the parametric system.

- Selecting public buildings for different activities to demonstrate the extent of the parametric system's success to revival modern Islamic architecture in any type of building and expressing the function of the building.

(5/4) The study sample:

The buildings on the researcher chosen are for the following buildings:

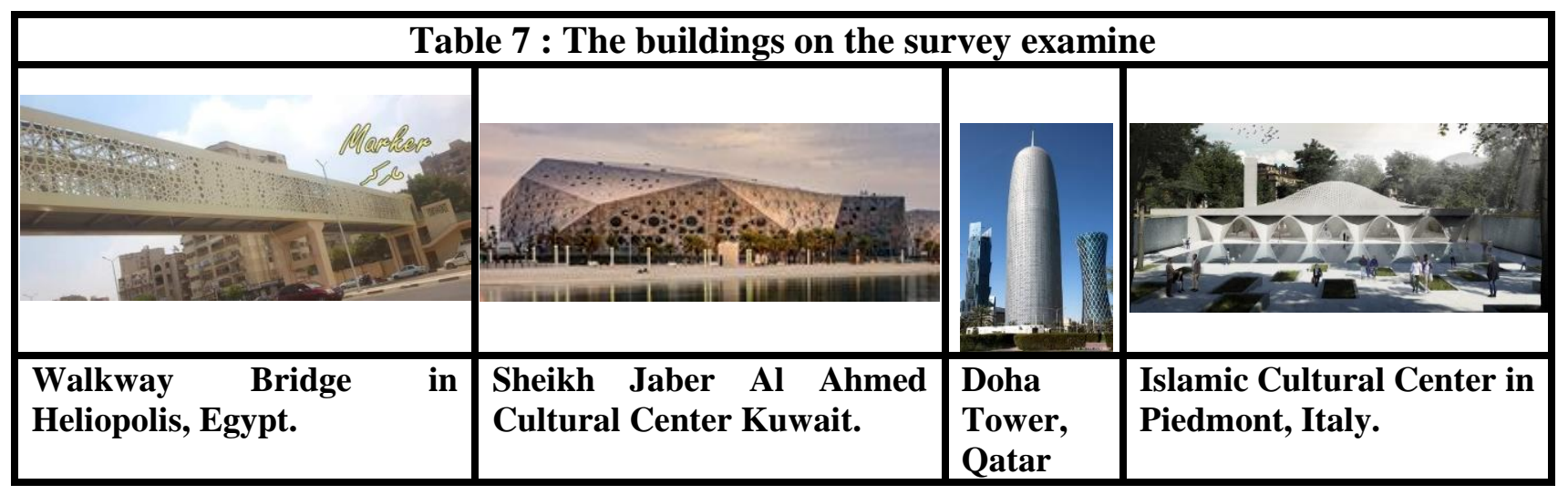




\section{6- The evaluation elements of the survey are:}

- The mass building (Traditional Islamic: like the old Islamic building, Contemporary Islamic: the building seems modern but it still have some Islamic elements, Modern building: not similar to any other Islamic building).

- Symmetrical: to explain if the right façade of the building is similar to the left side or not which represented in the evaluation (Symmetry: if they are the same, Unsymmetrical: if they are different).

- Stability: which means if the sides of the building are straight lines forming right angles or which not represents in the evaluation as (Stable if they form right angle, UN Stable if the sides are inclined).

- Repetition: if the mass buildings and elements have repeated before or not (Repeated the old Islamic architecture, Repeated with the spirit of Islamic arch., Unrepeated).

- The Islamic architecture elements (dome- minaret- mashrabyia- arches- pattern) used in (Contemporary modern: like the old one but in modern form, Traditional: the same like the old one, symbolic: the elements are found but with changes in its principles),

- Is the Islamic character of the building compatible with the surrounding environment (compatible: like the old Islamic buildings, not compatible: differ from the past).

- The effect of the shape of the Islamic building on the function of the building (Shape follow function, Shape follow function in a symbolic way, Shape not follow function)

- Materials (traditional: stone, brick, and glass, modern: fiber glass, steel and other materials).

- The effect of building materials on facades: the effects of the materials on the facades (contemporary modern, traditional)

- Construction system: the structure system of the buildings if it is (Traditional like the old Islamic buildings, contemporary modern: look like a modern one but still have the element of the Islamic architecture)

- Environmental treatment: the methods used to save energy (contemporary modern: like the old Islamic treatment but in modern design, traditional: the same like the old),

- Patterns : which uses to decorate the building if they are (modern Islamic patterns, geometric patterns),

- Did the building succeed in developing Islamic architecture into contemporary one? (Yes, no).

\section{7- Results from the survey}

We revealed from the survey some results: 


\section{(7/1) Result from the evaluation of the Walkway Bridge in Heliopolis, Egypt.}

Here is a chart for the biggest number and the smallest number from the survey for each element from the opinion of the Architecture and Non Architecture to get the final evaluation for each one which has the biggest number.

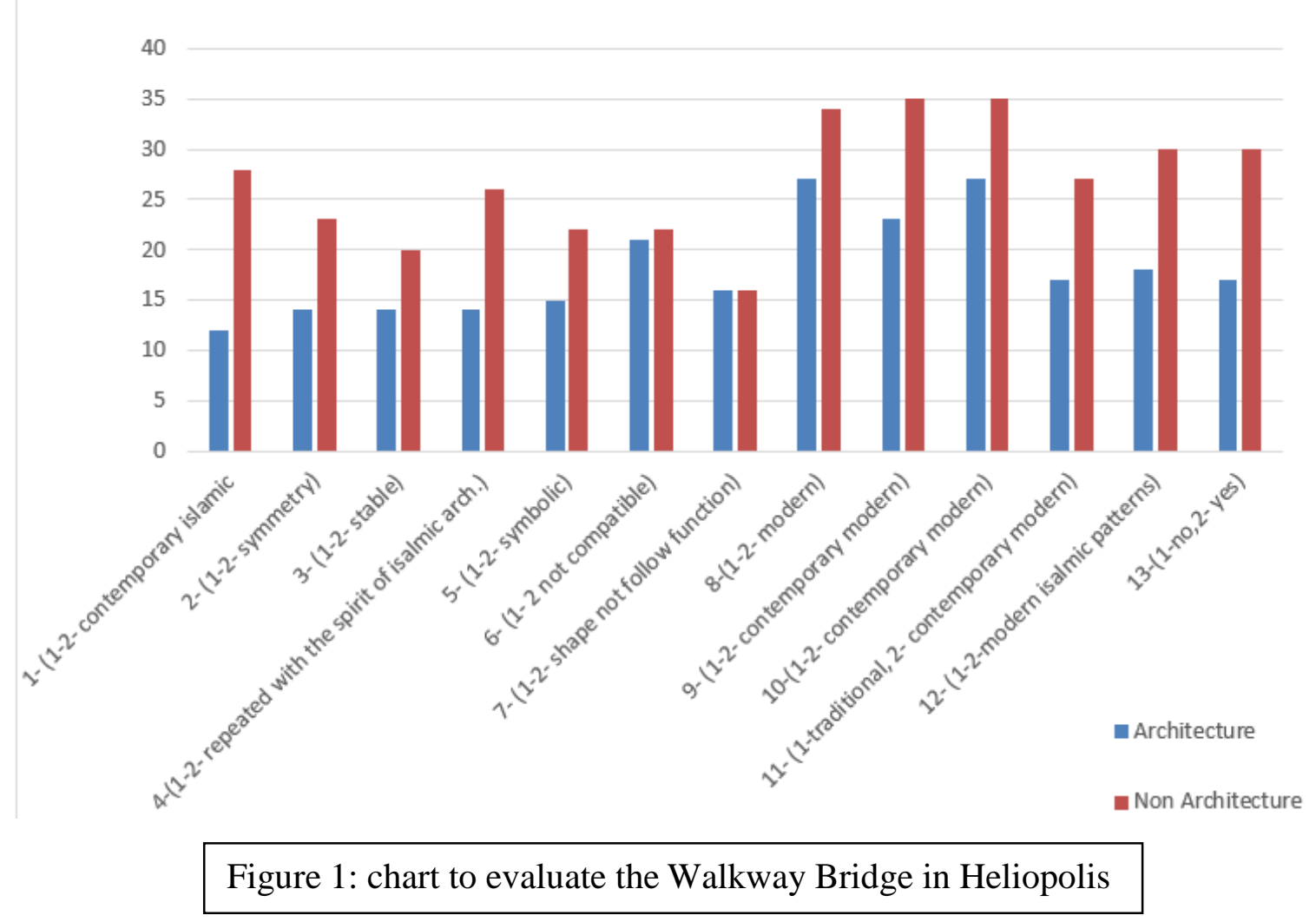

\section{(7/1/1) Finally the results are:}

- The mass building is Contemporary Islamic.

- The bridge is designed in a symmetrical way.

- The bridge is seen to be stable.

- The bridge repeated with the spirit of Islamic arch.

- The Islamic architecture elements (arches- pattern) used in symbolic design.

- The Islamic character of the bridge is non compatible with the surrounding environment.

- The shape of the Islamic building not follow the function of the building.

- The materials used to built the bridge are modern.

- The building materials gives the bridge a Contemporary modern look to the facades.

- The Construction system of the bridge is modern.

- They used Contemporary modern Environmental treatment.

- They used a modern Islamic patterns.

- Finally the bridge succeeded in developing Islamic architecture into contemporary one. 


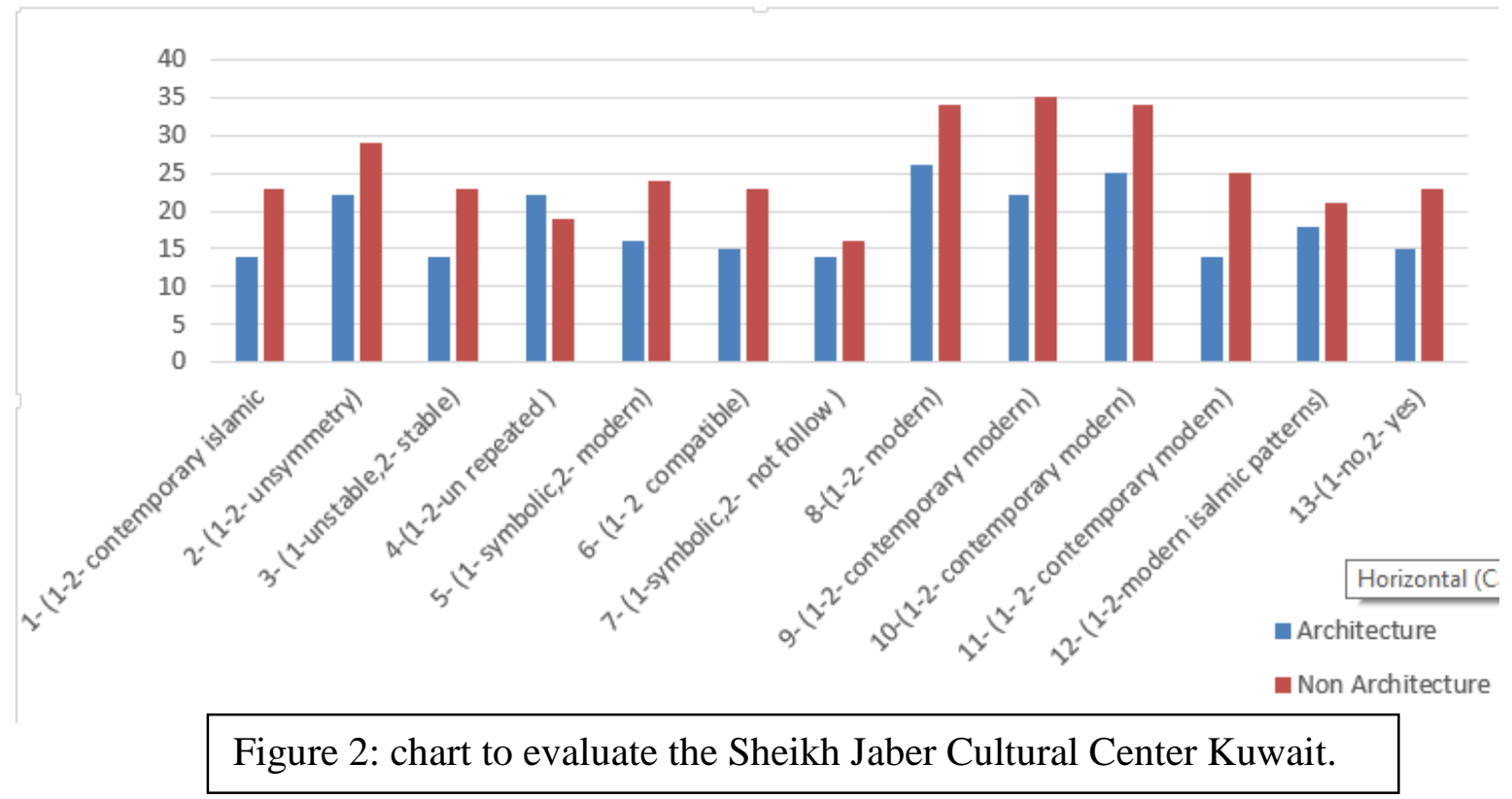

\section{(7/2/1) Finally the results are:}

- The mass building is Contemporary Islamic.

- The center is designed in a un symmetrical way.

- The center is seen to be stable.

- The center is seen to be un repeated (unique).

- The Islamic architecture elements (arches- pattern) used in Contemporary modern design.

- The Islamic character of the center is compatible with the surrounding environment.

- The shape of the Islamic building not follow the function of the building.

- The materials used to built the center are modern.

- The building materials gives the center a Contemporary modern look to the facades.

- The Construction system of the center is modern.

- They used Contemporary modern Environmental treatment.

- They used a modern Islamic patterns.

- Finally the center succeeded in developing Islamic architecture into contemporary one. 


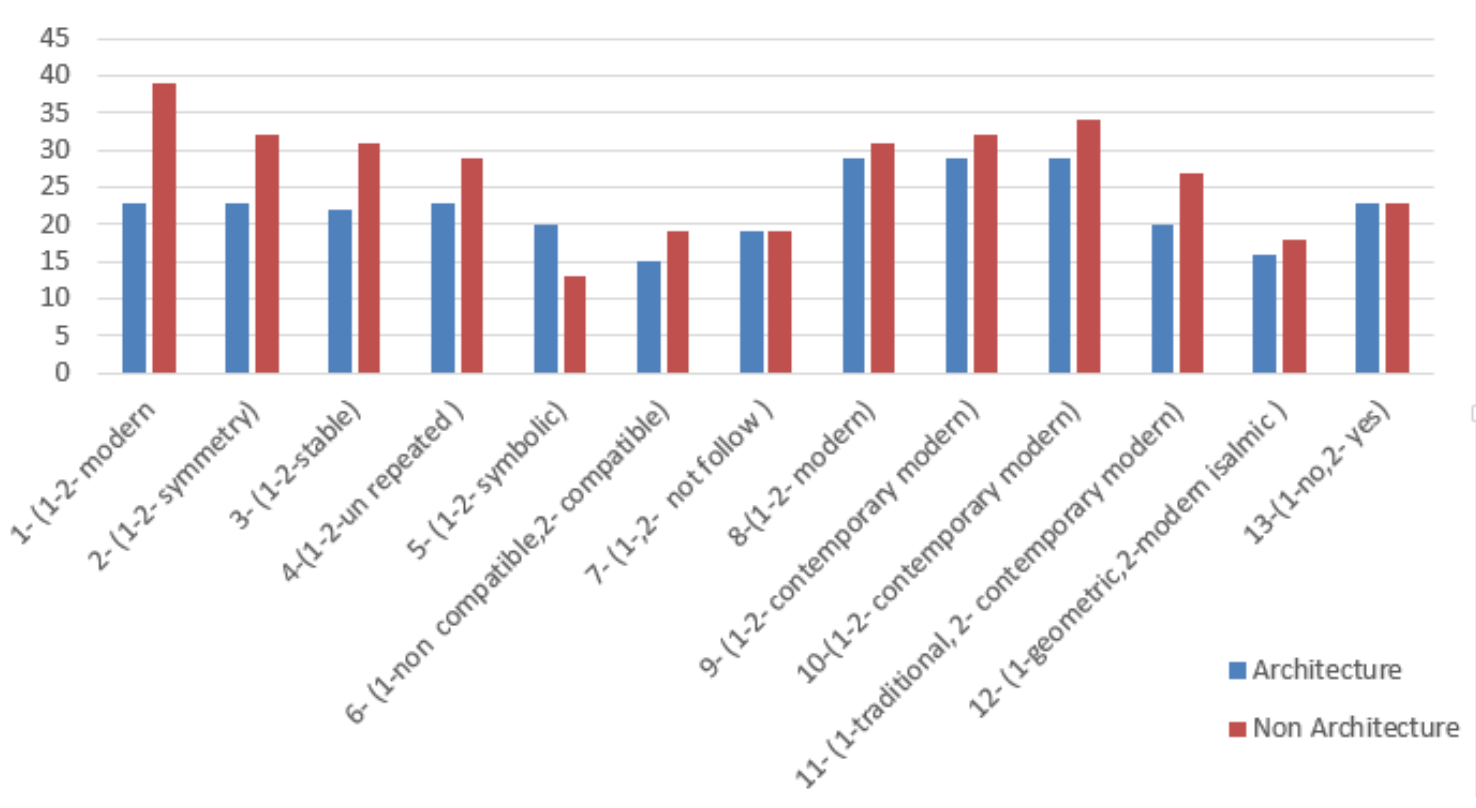

Figure 3: chart to evaluate the Doha Tower, Qatar..

\section{(7/3/1) Finally the results are:}

- The mass building is Modern building.

- The tower is designed in a symmetrical way.

- The tower is seen to be stable.

- The tower is seen to be un repeated (unique).

- The Islamic architecture elements (arches- pattern) used in symbolic design.

- The Islamic character of the tower is compatible with the surrounding environment.

- The shape of the Islamic building not follow the function of the building.

- The materials used to built the tower are modern.

- The building materials gives the tower a Contemporary modern look to the facades.

- The Construction system of the tower is Contemporary modern.

- They used Contemporary modern Environmental treatment.

- They used a modern Islamic patterns.

- Finally the tower failed in developing Islamic architecture into contemporary one. 


\section{(7/4) Result from the evaluation of the Islamic Cultural Center in Piedmont, Italy.}

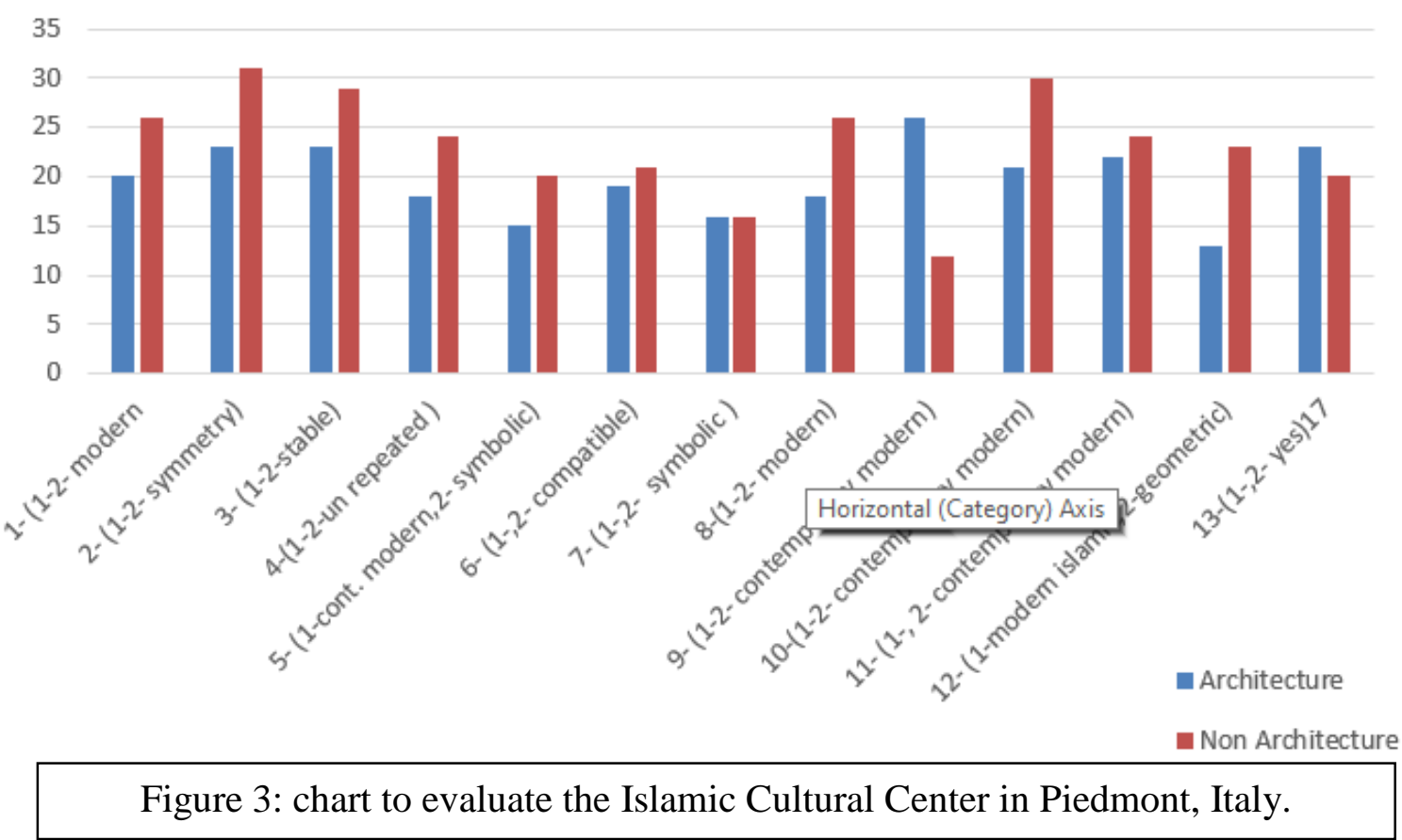

\section{(7/4/1) Finally the results are:}

- The mass building is modern.

- The center is designed in a symmetrical way.

- The center is seen to be stable.

- The center is seen to be un repeated (unique).

- The Islamic architecture elements (arches- pattern) used in symbolic design.

- The Islamic character of the center is compatible with the surrounding environment.

- The shape of the Islamic building follow the function of the building in a symbolic way.

- The materials used to built the center are modern.

- The building materials gives the center a Contemporary modern look to the facades.

- The Construction system of the center is Contemporary modern.

- They used Contemporary modern Environmental treatment.

- They used a modern Geometric patterns.

- Finally the center succeeded in developing Islamic architecture into contemporary one. 


\section{8- The final Results from the evaluation of each element from all buildings}

\begin{tabular}{|c|c|c|c|c|c|}
\hline $\begin{array}{l}\text { Elements of } \\
\text { evaluation }\end{array}$ & $\begin{array}{c}\text { Walkway } \\
\text { Bridge }\end{array}$ & $\begin{array}{c}\text { Sheikh } \\
\text { Jaber } \\
\text { Cultural } \\
\end{array}$ & $\begin{array}{l}\text { Doha } \\
\text { Tower }\end{array}$ & $\begin{array}{c}\text { Islamic } \\
\text { Cultural } \\
\text { Center } \\
\end{array}$ & $\begin{array}{l}\text { The final } \\
\text { result from } \\
\text { the survey }\end{array}$ \\
\hline The mass building & $\begin{array}{l}\text { Contemporary } \\
\text { Islamic }\end{array}$ & $\begin{array}{l}\text { Contemporary } \\
\text { Islamic }\end{array}$ & $\begin{array}{l}\text { Modern } \\
\text { building }\end{array}$ & $\begin{array}{l}\text { Modern } \\
\text { building }\end{array}$ & $\begin{array}{l}\text { Modern } \\
\text { building }\end{array}$ \\
\hline Symmetrical & Symmetry & Un Symmetry & Symmetry & Symmetry & Symmetry \\
\hline Stability & Stable & Stable & Stable & Stable & Stable \\
\hline Repetition & $\begin{array}{l}\text { Repeated with } \\
\text { the spirit of } \\
\text { Islamic arch. }\end{array}$ & Unrepeated & Unrepeated & Unrepeated & Unrepeated \\
\hline $\begin{array}{c}\text { The Islamic } \\
\text { architecture } \\
\text { elements (dome- } \\
\text { minaret- } \\
\text { mashrabyia- arches- } \\
\text { pattern) used in }\end{array}$ & symbolic & $\begin{array}{l}\text { Contemporary } \\
\text { modern }\end{array}$ & symbolic & symbolic & symbolic \\
\hline $\begin{array}{c}\text { Is the Islamic } \\
\text { character of the } \\
\text { building compatible } \\
\text { with the } \\
\text { surrounding } \\
\text { environment }\end{array}$ & $\begin{array}{c}\text { Non } \\
\text { compatible }\end{array}$ & compatible & compatible & compatible & compatible \\
\hline $\begin{array}{l}\text { The effect of the } \\
\text { shape of the Islamic } \\
\text { building on the } \\
\text { function of the } \\
\text { building }\end{array}$ & $\begin{array}{l}\text { Shape not } \\
\text { follow } \\
\text { function }\end{array}$ & $\begin{array}{c}\text { Shape not } \\
\text { follow function }\end{array}$ & $\begin{array}{l}\text { Shape not } \\
\text { follow } \\
\text { function }\end{array}$ & $\begin{array}{l}\text { Shape follow } \\
\text { function in a } \\
\text { symbolic way }\end{array}$ & $\begin{array}{l}\text { Shape not } \\
\text { follow } \\
\text { function }\end{array}$ \\
\hline Materials & Modern & Modern & Modern & Modern & Modern \\
\hline $\begin{array}{c}\text { The effect of } \\
\text { building materials } \\
\text { on facades }\end{array}$ & $\begin{array}{l}\text { Contemporary } \\
\text { modern }\end{array}$ & $\begin{array}{l}\text { Contemporary } \\
\text { modern }\end{array}$ & $\begin{array}{c}\text { Contemporary } \\
\text { modern }\end{array}$ & $\begin{array}{c}\text { Contemporary } \\
\text { modern }\end{array}$ & $\begin{array}{c}\text { Contemporary } \\
\text { modern }\end{array}$ \\
\hline Construction system & $\begin{array}{c}\text { Contemporary } \\
\text { modern }\end{array}$ & $\begin{array}{c}\text { Contemporary } \\
\text { modern }\end{array}$ & $\begin{array}{c}\text { Contemporary } \\
\text { modern }\end{array}$ & $\begin{array}{c}\text { Contemporary } \\
\text { modern }\end{array}$ & $\begin{array}{c}\text { Contemporary } \\
\text { modern }\end{array}$ \\
\hline $\begin{array}{c}\text { Environmental } \\
\text { treatment }\end{array}$ & $\begin{array}{c}\text { Contemporary } \\
\text { modern }\end{array}$ & $\begin{array}{c}\text { Contemporary } \\
\text { modern }\end{array}$ & $\begin{array}{c}\text { Contemporary } \\
\text { modern }\end{array}$ & $\begin{array}{c}\text { Contemporary } \\
\text { modern }\end{array}$ & $\begin{array}{c}\text { Contemporary } \\
\text { modern }\end{array}$ \\
\hline Patterns & $\begin{array}{l}\text { Modern } \\
\text { Islamic } \\
\text { patterns }\end{array}$ & $\begin{array}{l}\text { Modern } \\
\text { Islamic } \\
\text { patterns }\end{array}$ & $\begin{array}{l}\text { Modern } \\
\text { Islamic } \\
\text { patterns }\end{array}$ & $\begin{array}{l}\text { Geometric } \\
\text { patterns }\end{array}$ & $\begin{array}{l}\text { Modern } \\
\text { Islamic } \\
\text { patterns }\end{array}$ \\
\hline $\begin{array}{l}\text { Did the building } \\
\text { succeed in } \\
\text { developing Islamic } \\
\text { architecture into } \\
\text { contemporary one? }\end{array}$ & yes & yes & No & Yes & Yes \\
\hline
\end{tabular}


Here is a chart for final result for each element from each building to obtain the final conclusion of the survey.

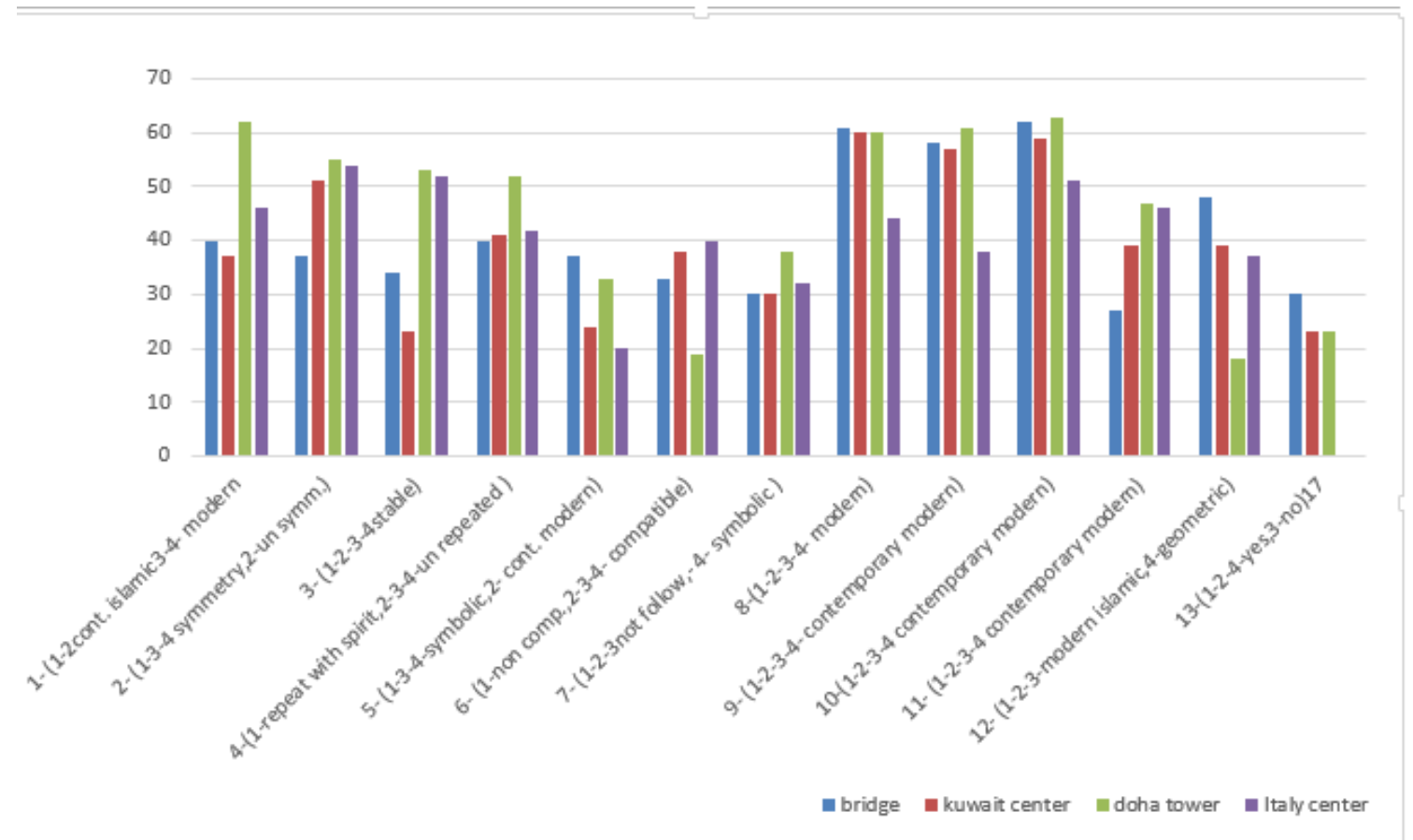

Figure 4: chart to obtain the final result from the survay.

\section{(8/1) The final results from the survey are:}

- The mass building of the Islamic parametric buildings are modern.

- The Islamic parametric buildings are designed in a symmetrical way.

- The buildings are seen to be stable.

- Each building is unique and not repeated.

- The Islamic architecture elements (arches- pattern) used in symbolic design.

- The Islamic character of the buildings are compatible with the surrounding environment.

- The shape of the Islamic building not follow the function of the building.

- The materials used are modern.

- The building materials gives the buildings a Contemporary modern look to the facades.

- The Construction system of the buildings are Contemporary modern.

- They used Contemporary modern Environmental treatment.

- They used a modern Islamic patterns.

- Finally the buildings succeeded in developing Islamic architecture into contemporary one by using the parametric algorithms. 


\section{8- Conclusion}

From the previous survey and the analytical studies we notice that some elements had changed some deleted and some new obtained, so we'll obtained:

\section{A methodology from both of them to revival the modern Islamic architecture by using parametric algorithms:}

- The Presence of the Islamic elements such as domes, minerates, mihrab and round arches, tunnel vaults, and richly decorated arabesque and calligraphy, but in symbolic parametric shape.

- The mass buildings become symmetry and stable in some building to looks like the old one from the first sight which mean it become unique, not repeated.

- Using the Islamic environmental treatment but re-represented it in Contemporary modern design.

- The Islamic geometric patterns changed in a contemporary design which fits the modern design of the building.

- The building materials of the contemporary Islamic parametric buildings changed from tradional one to Contemporary modern one.

- The contemporary Islamic parametric buildings are compatible with the surrounding environment.

- The shape of the contemporary Islamic design not follow function.

- The Construction system of the contemporary Islamic parametric buildings are Contemporary modern.

- When parametric algorithms used with Islamic architecture changed in shape not in the principles of its element.

- The contemporary Islamic parametric building must extracting from the past of Islamic architecture.

\section{9- References}

\section{First: Arabic reference}

$$
\begin{aligned}
& \text { 1- أ .د/ عبد الباقي إبر اهيم وشركاه ، مقال بعنو ان "الاصاله و المعاصرة في العمارة الاسلامية" ، رئيس مركز }
\end{aligned}
$$

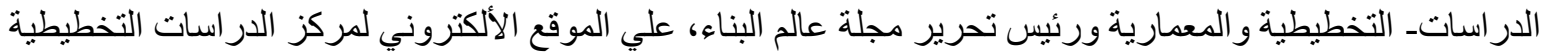

$$
\begin{aligned}
& \text { "https://www.cpas-egypt.com/?lang=ar . } \\
& \text { 2- أ.د/ عبد الباقي إبراهيم وشركاه ، مقال بعنوان "مر احل تطور العمارة في مصر في العصر الإلسالمي" ، رئيس مركز }
\end{aligned}
$$

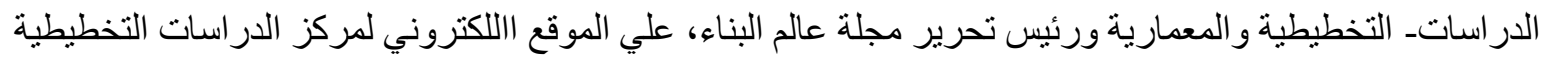

\section{Second: English reference}

3-Sara Mahmoud, "The development of the principles of the Elements of Islamic architectural by using parametric algorithms", paper in Helwan University,2021.

4-5-Mostafa Alani, Carlos Barrios, "parametric metamorphosis of Islamic geometric patterns: The extraction of new from traditional", Clemson University, 2015.

6- Christina Robev, Book "What is parametric design? ", Robazzo Design studio LTd, 2018.

7- Patrik Schumacher, "Design Parameters to Parametric Design", London 2014 Published in: The Routledge Companion for Architecture Design and Practice: Established and Emerging Trends, Edited by Mitra Kanaani and Dak Kopec, Routledge,Taylor and Francis, New York 2016. 
8- Roland Hudson, 'Strategies for parametric design in architecture'. An application of practice led research a thesis submitted for the degree of Doctor of Philosophy University of Bath Department of Architecture and Civil Engineering 2010.

\section{Third: Websites}

9- http://www.thearchitect'sdiary.com/ Islamic Cultural Center in Piedmont/ ( last visit: $1 / 12 / 2020)$

10- https://www.arch20.com/ Da Chang Muslim Cultural Center/ (last visit: 22/12/2020)

11- http://www.sure-architecture.com/ Yinchuan Exhibition Center/ (last visit: 15/1/2021)

12- https://architizer.com/ Ateliers Jean Nouvel's Marvelous Metallic Dome/ (last visit: 2/2/2021)

13-https://en.wikipedia.org/wiki/King_Abdullah_Petroleum_Studies_and_Research_Center/ (last visit 20/2/2021)

14- https://www.qf.org.qa/The Qatar Faculty of Islamic Studies/ ( last visit: 2/3/2021) 